\title{
Összefüggések a párkapcsolat szerkezete és felbomlása között a nemzetközi szakirodalom tükrében
}

\author{
ERÁT DÁVID \\ https://doi.org/10.51624/SzocSzemle.2019.3.2 \\ Beérkezés: 2018. 10. 26. \\ Átdolgozott változat beérkezése: 2019. 07. 23. \\ Elfogadás: 2019. 10. 11.
}

\begin{abstract}
Összefoglaló: Írásomban bemutatom a párkapcsolat szerkezete és felbomlása között felfedezhető kapcsolat elméleti hátterét, valamint a témában született válogatott empirikus kutatások eredményeit. A párkapcsolatok összetételét és minőségét tárgyaló elméletek közül gyakran alkalmazott Becker modellje, mely a hangsúlyt a párkapcsolatban lévő személyek specializációjára és kölcsönös egymástól függésére helyezi. A specializációs felfogással szemben viszont más elméletek a hasonlóság lehetséges pozitív hatásait - hasonló világnézet, jobb kommunikáció, egyező élethelyzetek - emelik ki. Az empirikus eredmények többnyire a specializációs modellt támogatják. Az alkudozási perspektíva szerint az erőforrások egyenlőtlensége aszimmetrikus döntési viszonyokat alakít ki a párkapcsolatban, ami növeli a kapcsolat instabilitását. Az alkudozási perspektívához köthető relációs kohézió elmélete szerint bizonyos tényezők mellett a felek egyenlótlen viszonyaiból is eredeztethető egy párkapcsolat stabilitása. A relációs kohézió által feltételezett folyamatokat a bemutatott kutatás eredménye igazolta. A kapcsolatok szerkezetének és tartósságának vizsgálatakor elengedhetetlen a párkapcsolati piacok és az uralkodó normák figyelembevétele. A makrostrukturális körülmények elősegíthetik bizonyos kapcsolatszerkezeti formák létrejöttét, és a lehetséges párkapcsolati alternatívák száma az egyéneket a kapcsolat felbontására hajlamosíthatja. A normák befolyásolják a különféle kapcsolatok megítélését a társadalomban (ezzel hatást gyakorolva stabilitásukra), a késleltetett forradalom elmélete szerint viszont a normák átalakulása csak lemaradva követi a tényleges strukturális változásokat. Az eredmények szerint a normák és a párkapcsolati piac átalakulásával összefügg a nem tradicionális kapcsolatok terjedése, valamint instabilitásuk csökkenése.
\end{abstract}

Kulcsszavak: homogámia, párkapcsolat szerkezete, specializáció, felbomlás, válás

\section{Bevezetés $^{1}$}

A hazai és nemzetközi tudományos, valamint közéleti diskurzusban növekvő figyelmet kap a párkapcsolatok felbomlása. Európában a válások száma nő (Eurostat

1 A tanulmány megírása során nyújtott segítségéért köszönettel tartozom Spéder Zsoltnak, valamint Berger Viktornak és Pirmajer Attilának.

A tanulmány az EFOP-3.6.3-VEKOP-16-2017-00007 azonosítószámú, „Tehetségből fiatal kutató. A kutatói életpályát támogató tevékenységek a felsőoktatásban" megnevezésű projektben, a Széchenyi 2020 program keretében, európai uniós (Európai Szociális Alap) társfinanszírozással valósult meg. 
2019), Magyarországon pedig egy hosszú növekedési tendencia 2010 után kezdett csökkenni (Makay-Szabó 2018).

A kutatók által régóta tanulmányozott kérdés, hogy mely tényezők határozzák meg egy párkapcsolat stabilitását - azaz a kapcsolat fennmaradását és a válási/szakítási hajlam hiányát. Ennek eredményeképpen jelentős számú, befolyásoló erővel rendelkező tulajdonság került feltárásra, kezdve az egyszerű demográfiai jellemzőktől a párkapcsolatban meglévő érzelmi és szexuális harmóniáig (áttekintéshez lásd: Gödri 2001). A párkapcsolatok felbomlását vizsgáló kutatások körében gyakran feltett kérdés, hogy a különböző tulajdonságok mentén mutatkozó hasonlóság vagy eltérés milyen hatást fejt ki, kiemelten a relatív társadalmi-gazdasági helyzet és kulturális jellemzők tekintetében.

A párkapcsolatban a felek egymáshoz viszonyított helyzete mentén elkülönülnek a homogám és heterogám szerkezetű kapcsolatok. Előbbi esetén a felek szocioökonómiai státusza azonos, míg utóbbiban eltérő. A heterogám párkapcsolatok továbbá elválnak aszerint, hogy a nő alacsonyabb (hipergám), vagy pedig magasabb (hipogám) relatív helyzetben van a férfihoz képest.

Jelen tanulmány elsődleges célja, hogy bemutassa, milyen lehetséges mechanizmusok határozzák meg a különböző szerkezetű párkapcsolatok stabilitását. A főbb elméletek bemutatása mellett válogatott nemzetközi tanulmányok és egy magyar kutatás eredményei is ismertetésre kerülnek, melyek hozzájárulnak a folyamatok összetettebb megismeréséhez. A párkapcsolatok felbomlási esélyét vizsgáló tanulmányok nagy száma miatt csak olyan vizsgálatok eredményei kerülnek bemutatásra, melyek célzottan a párkapcsolatszerkezet hatását vizsgálták a tanulmányban bemutatott elméletek alkalmazásával.

A tanulmány első részében a közgazdaságtanból származó specializációs modell, valamint annak alternatívájaként született szerephomofília-elmélet és módosított függetlenségi modell kerül ismertetésre. A második részben az alkudozási perspektíva és a relációs kohézió elméletéről lesz szó, melyek a párkapcsolat szerkezetére mint relatív alkupozíciókra tekintenek. Végül a makroszintű változásokat központba helyező, a párkapcsolati piacokkal és a normákkal foglalkozó megközelítések bemutatása történik meg.

\section{Különbségek vagy hasonlóságok?}

\section{Elméletek}

A Gary Becker nevéhez fúződő specializációs modell (Becker 1973, 1974, 1981) szerint a férfiak és nők között biológiai és szocializációs sajátosságokra visszavezethető különbség van, mely okán a nők és férfiak az élet más területein vannak előnyös helyzetben. Az elmélet szerint a férfiak a munkával és más jövedelemszerzéssel kapcsolatos tevékenységekben, a nők pedig a háztartáshoz köthető feladatokban 
képesek magasabb hasznot termelni. A párkapcsolat létrejötte előnyös az egyének számára, hiszen az erőforrások megosztása révén párjuk specializációval járó többlethaszna elérhetővé válik, így a párkapcsolatot választók jobb helyzetbe kerülnek, mint amire egyedülállóként képesek lennének. Ennélfogva a specializáció stabilitást eredményez a párkapcsolatban, mert kölcsönös függés, azaz interdependencia alakul ki. Az interdependens párkapcsolatok egyik jellegzetes (és Becker által idealizált) formája a kenyérkereső férfi és háztartásbeli nő alkotta házasság.

A specializációs modell szerint a kapcsolat felbomlására akkor kerülhet sor, ha a felek saját megítélése szerint képesek egyedülállóként is fenntartani jelenlegi helyzetüket (azaz nem függnek partnerüktől), vagy egy új kapcsolatban előnyösebb haszonszerzői pozícióba tudnak kerülni. Becker elméletében a nők munkavégzése és a férfiakéhoz közelítő társadalmi-gazdasági helyzete a párkapcsolatok, kiemelten a házasságok szempontjából bomlasztó hatású.

A specializációs modell az interdependencia fontosságát kiemelten a munkához és jövedelemszerzéshez köthető tulajdonságok kapcsán emeli ki. Az életmódhoz, életfelfogáshoz, világnézethez, valláshoz és értékekhez köthető sajátosságok esetében viszont a homogámiát tartja előnyösnek. E kulturális jellemzők tekintetében a hasonlóság a párkapcsolat szempontjából stabilizáló hatású, mert hajlamosítja az egyéneket a közös befektetésekre, mint például a gyerekvállalásra vagy közös tulajdon vásárlására.

A specializációs modell napjaink viszonyaira történő felhasználásával szemben több kritika is felhozható. Becker elmélete szűk történeti időszakra és társadalmi körülményekre alkalmazható, kiemelten az 1950-1980-as évekbeli USA-ra és bizonyos nyugat-európai államokra. A nők foglalkoztatottsága más országokban korán elterjedt (gondolva akár a posztszocialista államokra), így a nők nem csak háztartási és gyereknevelési tevékenységükkel, hanem keresetükkel is hozzájárulhattak egy kapcsolathoz.

Másrészt, Becker nemspecifikusan a nőket a háztartáshoz, míg a férfiakat a keresőmunkához köthető feladatokban tekinti előnyös helyzetben lévőknek. Az elmélet központjában ugyan az erőforrások megosztása áll, azonban nem mérlegeli a kenyérkereső nő és háztartásbeli férfi párkapcsolatát, ami szintén interdependens viszonyokat alakíthat ki.

Harmadrészt, a relatív viszonyokat leíró mutatók rendelkeznek gazdasági (ahol a hipergámia tekintett előnyösnek) és kulturális (mely esetben a homogámia preferált) aspektusokkal is, melyek ellentétes irányú hipotéziseket eredményeznek. Példaként érdemes megfontolni a végzettséget, ami gyakran vizsgált társadalmat strukturáló tényező. A legmagasabb iskolai végzettség összefügg az egyén gazdasági és kulturális jellemzőivel (például Bukodi-Róbert 2000; Sági 2010), így a specializációs elmélet alapján a végzettségbeli homogámia és a hipergámia előnyössége mellett is felhozhatók érvek. 
Becker specializációs elméletében látható volt, hogy az egyenlőtlen társadalmigazdasági viszonyokban gyökerező interdependencia elősegíti a kapcsolatok létrejöttét és fennmaradását, és a kulturális hasonlóságok a közös befektetéseken keresztül erősítik a kapcsolatot. A specializációs modellhez hasonlóan a nők gazdasági függetlenedésére instabilitást okozó tényezőként tekint több családdemográfiai kutatás (Cherlin 1992; Preston-Richards 1975, idézi Lee-Ono 2008: 1217-18; Oppenheimer 1997: 432). Ezen megközelítéseket összefoglalóan függetlenségi modellnek nevezik.

A specializációs/függetlenségi modellel szemben a szerephomofília elmélete (role homophily theory) szerint a társadalmi-gazdasági helyzet hasonlósága a párkapcsolatban összekötő és stabilizáló hatást fejt ki. Simpson és England (1981: 185-186) elméletében a társadalmi-gazdasági helyzet a kulturális sajátosságok forrása, nem pedig attól független tényező. A hasonló szocioökonómiai helyzet így hasonló életcélokkal, értékekkel, életfelfogással jár, melyek tekintetében a homogámia előnyös a párkapcsolat fennmaradásának céljából. Ennek oka, hogy a pár tagjainak hasonlósága miatt a közös kommunikáció minősége, valamint a szolidaritás és az összetartozás mértéke magasabb. Ezzel szemben a heterogámia rossz kommunikációval, a szolidaritás alacsony mértékével és nemek szerint elkülönülő szerepekkel jár.

Míg Simpson és England a társadalmi-gazdasági és kulturális jellemzők közötti összefüggésekre mutatott rá, más kutatók a Becker által a nők javuló helyzetének tulajdonított kizárólagosan negatív hatást vonták kétségbe. A módosított függetlenségi modell (revised independence modell) kiemelten a relatív jövedelmi helyzetre fókuszál a párkapcsolatban (Cherlin 1979; Ross-Sawhill 1975, idézi Brennan-BarnettGareis 2001: 169-170; Oppenheimer 1997: 431-442). A modell szerint bármely fél jövedelme emeli a pár életminőségét, ezáltal csökkentve a párkapcsolat felbomlásának esélyét. A férfiak jövedelmének emelkedése kizárólag stabilizáló hatású, míg a nők magasabb keresete részben okozhat instabilitást is. Eme instabilitás forrása a már korábban ismertetett függetlenedési folyamat, mely együttesen jelentkezhet a női kereset párkapcsolat egészére kifejtett stabilizáló hatásával.

\section{Korábbi empirikus eredmények}

A relatív társadalmi-gazdasági helyzet és a párkapcsolati stabilitás összefüggéseiről számos nemzetközi kutatás született az évek során. Az alábbiakban három európai és egy magyar vizsgálat eredményeit ismertetem. A bemutatott tanulmányok különböző országokban és eltérő jellegű mintákon készültek, így átfogóbb képet kaphatunk az elméletek mellett vagy ellen szóló empirikus adatokról.

Frimmel, Halla és Winter-Ebmer (2013) kutatásában a kulturális hasonlóság, valamint a pár relatív végzettségének hatását vizsgálták osztrák adatokon. Az elemzéshez a szerzők az 1971 és 2007 között Ausztriában megköttetett összes házasság és végbement válás adatait használták fel. Ausztriában a bevándorlás növekedésével a vallásilag és etnikailag vegyes házasságok aránya is emelkedett (Frimmel et al. 2013: 917), így a kulturális homogámia és heterogámia kutatása osztrák mintán különleges nézőpontot kínál. 
A szerzők a házas felek kulturális hasonlóságát az etnikum és a vallásosság tekintetében vizsgálták. Az eredmények a korábban bemutatott elméletek szerint várható hatásokat igazolták, miszerint a pár tagjainak kulturális különbözősége növeli a párkapcsolat felbomlásának esélyét. Az első házasságok esetében egy homogám osztrák párhoz képest egy vegyes házaspár 26,1\% és 41,4\%-kal nagyobb eséllyel vált el, attól függően, hogy a feleség vagy a férj a külföldi állampolgár. Ezzel ellentétesen, ha a házaspár mindkét tagja külföldi hátterű, az osztrák házasokhoz képest 40-60\%-kal alacsonyabb eséllyel bomlott fel a kapcsolat. A szerzők szerint ennek oka az Ausztriába érkező bevándorlók tradicionálisabb attitűdje a házasság felé.

A vallásos homogámia vizsgálata során hasonló eredmények születtek. Egy katolikus házaspárhoz képest egy katolikus és más vallású személy házassága 26,4\%kal, míg egy katolikus és nem vallásos egyén kapcsolata 39,3\%-kal nagyobb eséllyel bomlott fel. Más vallások esetében szintén a vegyes kapcsolatok bizonyultak instabilabbnak, átlagosan körülbelül 40\%-kal. Időben leginkább tartósnak a vallásilag homogám, kiemelten a muszlimok és ortodox keresztények házasságai mutatkoztak. Frimmel és munkatársainak eredményei igazolták a kulturális hasonlóság feltételezett pozitív hatását a házasságok esetében.

A végzettség alapú homogámia esetében a specializációs modell bizonyult igaznak. A végzettség tekintetében az osztrák házasok 65\%-a volt homogám, időben pedig növekedett a hipogám házasságok aránya. A strukturális változások ellenére ugyanakkor a hipergám házasságok voltak időben a leginkább stabilak az adatok szerint: 17\%kal kisebb eséllyel bomlottak fel a homogám referenciacsoporthoz képest. Ha a feleség végzettsége viszont magasabb volt a férjéénél, a házasság felbomlásának esélye több mint negyedével $(27,4 \%)$ nőtt a homogám kapcsolatokhoz viszonyítva.

Kraft és Neimann (2009) szintén a végzettség és a vallás házasságot stabilizáló hatását vizsgálták a Socio Economic Panel Nyugat-Németországra vonatkozó adatainak felhasználásával. A követéses vizsgálatban a szerzők 1281 házaspárt elemeztek 1984 és 2007 között. A szerzők kutatásukban a specializációs modellt tesztelték, ugyanakkor az eredmények rávilágítanak arra, hogy a stabilitás-instabilitás nem feltétlenül a relatív viszonyokon múlik, egyes faktorok önmagukban befolyásolhatják egy párkapcsolat kimenetét.

A szerzők individuális szinten és relatív viszonyokként értelmezve is vizsgálták a végzettség, valamint a vallás hatását. Egyéni szinten a magasabb végzettség stabilabb házasságot jelentett mindkét nem esetében, míg az aktív vallásosság csak a férfiaknál fejtett ki pozitív hatást. A társadalmi-gazdasági helyzethez köthető változók hatása szintén nemspecifikus volt. A nők munkával töltött idejének növekedésével együttesen nőtt a válás esélye, a férjek esetében viszont a magasabb munkaóra magasabb stabilitással járt együtt. A munkanélküliség a férfiaknál erősen növelte a házasság felbomlásának esélyét.

A házastársak társadalmi-gazdasági helyzetét relatív viszonyban vizsgálva komplexebb kép mutatkozott. Az eredmények alapján a stabilitás tekintetében nem 
a pár tagjainak egymáshoz viszonyított végzettsége, hanem a végzettség abszolút szintje volt meghatározó. Függetlenül attól, hogy a kapcsolat heterogám vagy homogám, az alacsony végzettséggel rendelkezők válási esélye minden esetben magasabbnak mutatkozott. Ezzel ellentétben a magas végzettségűek kapcsolatai mindig stabilabbnak bizonyultak, függetlenül párjuk végzettségétől.

A vallásosság esetében hasonló hatás volt látható, a válás valószínűsége azoknál volt a legkisebb, ahol mindkét fél aktív vallásgyakorló. A felbomlás esélye nagyobb azon házasságokban, ahol csak az egyik fél vallásos - viszont a nem vallásos párok is nagyobb válási valószínűséggel rendelkeztek. Az eredmények alapján tehát nem a vallásos aktivitásban mutatkozó hasonlóság volt stabilizáló hatással, hanem a vallásosság maga.

Jalovaara (2003) finn mintán vizsgálta a társadalmi-gazdasági helyzet hatását a válás esélyére, szintén a specializációs nézőpontból. A szerző az elemzéshez finn népszámlálási és válási adatokat használt fel, 766637 pár bevonásával az 1991 és 1993 közötti megfigyelési időszakban. Az eddig ismertetett kutatásoktól eltérően a házas felek társadalmi-gazdasági helyzete a végzettség mellett a gazdasági aktivitás és jövedelem figyelembevételével is elemzésre került.

Jalovaara eredményei szerint a finn házastársak szocioökonómiai pozíciója között általában pozitív kapcsolat van. A házasságok 59\%-a volt végzettség tekintetében homogám, 66\%-a kétkeresős, és a párok 30\%-ában volt a házas felek jövedelme hasonló.

Az osztrák eredményekhez hasonlóan a finn párok végzettségének átlagos növekedése jelentősen csökkentette a válás rizikóját. A válás esélye a végzettség tekintetében homogám kapcsolatokban volt a legkisebb, heterogámia esetén (kiemelten az alacsony-közepes és alacsony-magas végzettségú házasságoknál) a válás kockázata jelentősen megnőtt. A tanulmány egyik fő megállapítása, hogy a végzettség átlagos növekedésének stabilizáló hatása, valamint a heterogámiával járó emelkedett válási esély nem volt nemhez kötött.

A végzettség esetében ugyan a homogámia pozitív hatása mutatkozott meg, más társadalmi-gazdasági mutatók vizsgálata során eltérő eredmények születtek, melyek a specializációs modell feltételezéseit támogatják. A kétkeresős házasságok válási esélye ugyan alacsony volt, a legstabilabbnak mégis a tradicionális, egykeresős kapcsolatok mutatkoztak. Ha az egyik fél munkanélküli volt, a válás esélye megnőtt, ugyanakkor a férfiak munkaerőpiacról való kimaradásának hatása erősebbnek bizonyult. A két munkanélküli által alkotott házasságok bomlottak fel a legnagyobb valószínűséggel. A házastársak jövedelmének vizsgálatakor Jalovaara a legalacsonyabb kereseti csoportban lévő házasokat használta referenciaként. Az eredmények alapján a válás esélye az alacsony keresetű feleség és magas keresetú férj alkotta párok esetén volt a legkisebb. A válás esélye megnőtt, ha a férj keresete nem érte el feleségéét, ilyen esetben a válás rizikója konzisztensen nőtt a feleség jövedelmével.

Magyarországi adatok felhasználásával Pilinszki (2015) szintén az instabilitást meghatározó tényezőket elemezte. A szerző az Életünk fordulópontjai 2008-as, reprezentatív panelmintáját, valamint egy kis elemszámú, de diádikus családsegítői min- 
tát használt fel. A diádikus minta előnye, hogy az adott párkapcsolatban élő mindkét személy válaszai rendelkezésre állnak. A családsegítői mintában szereplő egyének végzettség és foglalkoztatottság tekintetében rosszabb helyzetúek voltak, mint a reprezentatív minta tagjai, illetve nagyobb arányuk élt élettársi kapcsolatban.

Pilinszki az instabilitást a válásról való gondolkodás függvényében vizsgálja. A reprezentatív mintához képest a családsegítői mintában többszörös volt a váláson gondolkodók aránya a férfiak és nők esetében is (24,3\% és $21,4 \%$, szemben az 5,3\% és 9,1\%-kal). A válásról való gondolkozásra több háttérváltozó is hatással volt. A nőknél a szülők párkapcsolatának felbomlása, a házasság előtti együttélés, a fiatal gyermek jelenléte és a nem vér szerinti gyermekkel való együttélés növelte a kapcsolat felbontásról való gondolkozás esélyét. A férfiaknál e hatások nem érvényesültek.

A szocioökonómiai státusz tekintetében a reprezentatív mintában a nók végzettségének növekedésével nőtt a válásról való gondolkozás esélye, míg a diádikus mintánál ez a hatás nem jelentkezett. Pilinszki szerint ez az utóbbi mintában szereplő egyének általánosan rossz anyagi helyzetéből következik: egy esetleges szétválás esetén mindkét félnek meg kell oldani a lakhatást és a háztartás vezetését is, ami jelentős anyagi terhekkel jár. A végzettség tekintetében a homogámiának és heterogámiának nem volt szignifikáns hatása.

A vallásosság tekintetében a férj vallásossága csökkentette a válási hajlandóságot a partnerénél is, azonban a nők vallásossága (a partnerük esetében is) ellenkező hatást fejtett ki. A férfiak esetében a vallásilag heterogám kapcsolatokban élők nagyobb eséllyel gondoltak a kapcsolat megszakítására a családsegítői mintában.

A bemutatott kutatási eredmények alapján látható, hogy a kulturális tényezők hasonlósága egyértelműen csökkenti a kapcsolat felbomlásának esélyét. A relatív társadalmi-gazdasági helyzet tekintetében a hatásirány nem ilyen egyértelmú, ugyanakkor az eredmények többsége a specializációs modellt támogatja. A német és finn eredmények esetében felmerül, hogy a relatív viszonyokat (különösen a végzettség esetén) a hasonló-különböző dichotómia helyett részletesebben érdemes vizsgálni. Továbbá, a magyar eredmények tanulsága szerint a szegénység kényszerűségből összetartó hatását mérlegelni kell a relatív helyzetek vizsgálatakor is.

\section{Relatív helyzetek mint alkupozíciók}

\section{Elméletek}

Az eddig ismertetésre került elméleti megközelítések a párkapcsolat szerkezetét a kölcsönös függőség/függetlenség, illetve a kulturális hasonlóságok nézőpontjából értelmezték. Az alkudozási perspektíva (bargaining perspective) szerint viszont a párkapcsolatokban a felek a rendelkezésre álló erőforrásaik mentén alkupozíciókat foglalnak el (England-Farkas 1986, idézi Lee-Ono 2008: 1218; Bittman et al. 2001: 1-3, 2003: 188-190). Ha a kapcsolat heterogám a társadalmi-gazdasági helyzet te- 
kintetében, akkor egyenlőtlenek az alkupozíciók, így a döntések meghozatalában sem egyenlő mértékben vesznek részt a pár tagjai. Az adott alkuhelyzettel elégedetlen személyek számára az alternatívát a párkapcsolat felbontása jelenti.

Látható, hogy az alkudozási perspektíva szerint az egyenlőtlen szocioökonómiai viszony szükségszerủen az egyik fél elnyomásához vezet egy párkapcsolatban egyenlő alkupozíciókat csak a homogám kapcsolatok kínálhatnak. Lawler és Yoon hasonló megközelítéssel vizsgálták a kapcsolatok fennmaradásának folyamatait (Lawler-Yoon 1993, 1996), ugyanakkor elméletükben a társadalmi-gazdasági pozíciók egyenlőtlensége nem feltétlenül eredményez elnyomó viszonyt. Lawler és Yoon relációskohézió-elméletében (relational cohesion) a párkapcsolat fennmaradását a magas fokú elköteleződés eredményezi, mely a heterogám és homogám kapcsolatokban is kialakulhat.

A heterogám kapcsolatokban a felek összesített strukturális hatalma (más szóval a közös erőforrások mértéke) nagy, viszont alkupozícióik eltérőek. Ilyen esetben a pár tagjai engedményeket tesznek egymás felé az összesített strukturális hatalom megmaradása érdekében, ami mindkét fél számára kívánatos állapot. Ha az alkudozások sikeresek, pozitív érzelmi kapcsolat és mély elköteleződés alakul ki a pár tagjai között, és a kapcsolat stabilitása megnő. E nézőpontból egy heterogám kapcsolat fennmaradásának kulcspontja egyfelől a magas összesített strukturális hatalom, másfelól a sikeres alkudozás, mely integratív hatással (integrative bargaining) bír. A heterogám párkapcsolatban az egyének nem érdekeltek az alkudozásban és az azzal járó kompromisszumokban, ha a közösen elérhető strukturális hatalom mértéke alacsony. A relációs kohézió elméletének e része hasonló a specializációs modellhez: a pár tagjai egymásra vannak utalva, érdekükben áll erőforrásaik megosztása egymással, és a magas kölcsönös haszon esetében a kapcsolat stabilabb.

A társadalmi-gazdasági helyzet szempontjából homogám kapcsolatokban viszont a kohézió forrása az egyenlő hatalom. Ez esetben a felek nem összesítve rendelkeznek nagymértékú strukturális hatalommal, hanem külön-külön azonos mértékủ hatalommal bírnak, valamint alkupozícióik is egyezők. Az alkupozíciók hasonlósága miatt a felek a döntéshozatalban egyenlóként vesznek részt, így a kapcsolatban a stabilitás forrása a sikeres megegyezésekből következő pozitív érzelmek és elköteleződés. Míg a heterogám kapcsolatokban tehát fontos a közös célként megjelenő magas strukturális hatalom, a homogám párkapcsolatok esetében kizárólag az egyének alkudozásának sikeressége a meghatározó a párkapcsolat fennmaradása szempontjából.

\section{Korábbi empirikus eredmények}

A relációs kohézió elméletét Brines és Joyner (1999) az amerikai Panel Study of Income Dynamics huszadik hullámának reprezentatív adatain vizsgálták. A kutatók feltételezése szerint a házasságok jobb alapot nyújtanak az egyenlőtlen helyzetű felek integratív alkudozására, mert a házastársakat különféle jogi szabályozások védik 
(például egy házassági szerződés) az egyenlőtlenségből adódó rizikóval szemben. Az élettársi kapcsolatok informálisabb jellege miatt az eltérő hatalmi helyzet mindkét fél számára túl nagy kockázatot jelent, így az egyenlő hatalomra épülő kohézió kialakulása várhatóbb e kapcsolatokban. A párkapcsolatban lévő relatív társadalmigazdasági viszonyokat a szerzők a foglalkoztatottság típusa (nem foglalkoztatott, részmunkaidő és teljes állás) és a relatív jövedelem segítségével, míg a strukturális hatalmat a pár összjövedelmével mérték.

Brines és Joyner eredményei szerint az élettársi kapcsolatban élő nők a házasokhoz képest több időt töltenek fizetett munkával, és jövedelmük átlagosan eléri a partnerük jövedelmének 90\%-át. Ezzel szemben a házas nők átlagosan mindöszsze $60 \%$-át keresik a férjük jövedelmének. Továbbá, az élettársi kapcsolatokban élő nők nagyobb eséllyel kerestek többet párjuknál, mint a feleségek. Az eredmények konzisztensek a szerzők feltételezésével, miszerint az élettársi kapcsolatokban az egyének társadalmi-gazdasági helyzete átlagosan egyenlőbb, mint a házasságokban. Ezt ugyanakkor magyarázhatja az is, hogy az egalitáriusabb beállítódású egyének inkább élettársi kapcsolatokat választanak házasság helyett.

A kapcsolat felbomlásának esélyét vizsgáló statisztikai modellek eredményei szerint teljesen eltérő mechanizmusok befolyásolják a párkapcsolat stabilitását a két kapcsolattípusban. Az élettársi kapcsolatokban a tartósság az egyenlő viszonyok függvénye, míg a házasok esetében a pár egyenlőtlen helyzetéből (specializáltságából) következik. Az élettársi kapcsolatok kisebb eséllyel bomlottak fel, ha a pár tagjainak keresete megközelítette az egyenlő szintet. A házasok esetében viszont ellentétes folyamat játszódott le: minél inkább közelítette a feleség keresete a férjéét, annál inkább nőtt a válás esélye. A házasok esetében továbbá csökkentette a válás esélyét a magasabb strukturális hatalom (közös jövedelem).

Brines és Joyner eredményi alapján tehát az élettársi kapcsolatokat az egyenlő hatalomra épülő kohézió, míg a házasságokat az egyenlőtlen viszonyokból eredő integratív folyamatok és a magas strukturális hatalom párosa tartja össze. Azon élettársi kapcsolatok, melyekben csak a férfi volt foglalkoztatva 2,75-ször nagyobb eséllyel bomlottak fel, mint amelyekben egyenlő viszonyok uralkodnak. A házasságok ugyanakkor rugalmasabbnak mutatkoztak az „ideális” helyzettől való eltérés esetén: ha a feleség keresete kétszerese volt férjéének, 1,6-szeresére nőtt csak a válás esélye.

\section{Makroszintű hatások}

\section{Párkapcsolati piacok}

Az eddigiekben bemutatott elméletek és eredmények alapján látható, hogy a párkapcsolat szerkezetének hatása van a kapcsolat stabilitására. Azonban további kérdést jelent, hogy az adott társadalomban egyáltalán milyen összetételű kapcsolatok tud- 
nak létrejönni. A párkapcsolati piac, mely a lehetséges partnerek számát és jellemzőit jelenti, befolyással van a létrejövő kapcsolatok szerkezetére és tartósságára.

Blau makrostruktúra-elmélete szerint a társadalom csoportjainak mérete meghatározza a társadalmi életet (Blau 1977: 40-50) és az interakciók gyakoriságát bizonyos társadalmi-gazdasági helyzetủ egyének között. Ha a társadalomban megnő egy bizonyos csoport (például a magasan képzett nők) aránya, nagyobb az esélye, hogy egy partnert kereső személy a csoport tagjával kezdeményez kapcsolatot.

A makrostruktúra-elmélet azonban figyelmen kívül hagyja, hogy a párt kereső egyének nem véletlenszerúen mozognak az adott társadalomban. A mindennapok általában sajátos összetételű alstruktúrákban, más néven helyi párkapcsolati piacokon (Kalmijn 1998: 402-404) telnek el. Ilyen speciális alstruktúrák például az oktatási intézmények (kiemelten a felsőoktatás), szomszédságok, munkahelyek, ahol többnyire hasonló társadalmi-gazdasági helyzetű egyének fordulnak meg.

A párkapcsolati piac időben viszont változó képet mutat. Európa legtöbb országában és az USA-ban a férfiak és nők közötti társadalmi-gazdasági különbségek csökkentek, a végzettség esetében pedig a hatvanas évektől a nők vannak előnyösebb helyzetben (Van Hek et al. 2016: 268-271). Ennek eredményeképp egyes kutatók szerint a végzettség szerint hipergám kapcsolatok aránya rövid időn belül minimálisra fog csökkenni, ezzel egyidejűleg pedig emelkedni fog az olyan kapcsolatok aránya, melyben a nő számít fő keresőnek (Esteve et al. 2016: 4-9).

Összességében, a párkapcsolati piac összetétele és változó jellege növeli a valószínűségét bizonyos összetétű kapcsolatok létrejöttének. A stabilitás kérdése szempontjából kulcsfontosságú, hogy a jelenlegi párkapcsolatához képest az egyén milyen alternatívákkal találkozik mindennapjai során.

South és munkatársai szerint a párkapcsolat felbomlásának esélye jelentősen megnő, ha az egyik fél előnyösebb partnert talál a jelenleginél (South et al. 2001: 744). A specializációs modell szemszögéből ez lehet egy olyan személy, aki több erőforrást kínál a párkapcsolatban, a szerephomofília szemszögéből pedig egy olyan potenciális partner, akinek szocioökonómiai helyzete hasonló, és a kulturális jellemzők közösek. Továbbá, a vonzó alternatíva jelenthet egy olyan kapcsolatot, melyben az egyén alkupozíciója elfogadhatóbb a jelenleginél.

Természetesen nem minden egyén lép ki a párkapcsolatából egy potenciálisan jobb kapcsolatért. A jelenlegi pár iránti elköteleződést jelentősen növelik a kapcsolatspecifikus befektetések, mint a közösen eltöltött idő, a gyerekvállalás és a közös tulajdon, valamint a jogi környezet, mely nehezítheti és költségessé teheti a válást (Rapp et al. 2015: 234-235).

\section{A normák szerepe}

A párkapcsolati piacok időbeli változása mellett fontos kontextust jelent, hogy az adott társadalom hogyan tekint bizonyos szerkezetű párkapcsolatokra. A tradicionális nemi felfogásokkal rendelkező társadalmakban a párjuknál alacsonyabb 
társadalmi-gazdasági helyzetű férfiak, illetve a kenyérkereső nők a társadalom számonkérésével, a rokonok és közeli szociális közegek negatív megítélésével, valamint a nemi identitásuk kétségbevonásával számolhatnak (Brines 1994, idézi Blossfeld - Timm 2003: 9-10).

Blossfeld és Timm (2003: 8-10) e negatív hatás időbeli gyengülését feltételezi, összekötve a párkapcsolati piac változását a normák átalakulásával. Érvelésük szerint a nők foglalkoztatottságának normalizálódásával és a kétkeresős családok terjedésével a nők jövedelmének meghatározó szerepe lett a pár életszínvonalának biztosításában. A férfiak számára így előnyössé és társadalmilag elfogadottá vált a magasan képzett, nagy jövedelemmel rendelkező nők preferálása - miközben a párkapcsolati piacon egyre nagyobb eséllyel találnak ilyen párt.

A Blossfeld és Timm által felvázolt normalizálódási folyamattal szemben eltérő álláspontot képvisel England (2010), aki a nemek közötti viszonyok átalakulását egyenlőtlennek és késleltetettnek (uneven and stalled) titulálta. England szerint az egyenlőtlenség forrása, hogy a nőkkel azonosított jellemvonások és aktivitások kulturálisan elértéktelenedtek, így a férfiak nem motiváltak a kevésbé jutalmazott tradicionális női feladatokat ellátni. Ezzel ellentétben a nők viszont gazdasági okok miatt egyre nagyobb arányban lépnek be a férfi terekbe (munkavégzés és tradicionálisan férfiak által végzett feladatok).

A változások továbbá késleltetettek, mert hiába emelkedik a hipogám kapcsolatok aránya, a társadalom számára továbbra is normaszegőnek, vagy legalábbis különösnek hatnak, ezért a válás és szeparáció esélye nagyobb e kapcsolatszerkezeti típusokban. Érdekes jelenség, hogy a kenyérkereső nő és háztartásbeli férfi által alkotott kapcsolatokban a pár tagjai ezért gyakran különböző stratégiákat alkalmaznak a férfi alacsonyabb társadalmi-gazdasági helyzetének elrejtésére (Tichenor 1999: 648).

\section{Korábbi empirikus eredmények}

A késleltetett forradalom gondolata szerint a strukturális átalakulásokat nem követte a normák megváltozása, más kutatók szerint viszont a hipogám kapcsolatok arányának elkerülhetetlen növekedésével elfogadottságuk nő, ezzel stabilitás tekintetében hasonulnak a homogám és hipergám kapcsolatokhoz. Schwartz és Han (2014) tanulmányukban e két elgondolást vizsgálták hét különböző egyesült államokbeli forrásból származó adatbázison, mely az 1973-2010 közötti időszakot öleli fel. A szerzők a férfiak és nők relatív társadalmi-gazdasági helyzetét a végzettség, jövedelem és foglalkoztatottság tekintetében vizsgálták.

Az eredmények alapján az USA-ban az 1980-as éveket követően jelentősen nőtt a végzettség szerint hipogám kapcsolatok aránya, az összes házasság esetében ez elérte a 30\%-ot, a 2005-2009-es házasodási kohorsz esetében pedig a 60\%-ot. Ezzel párhuzamosan megváltozott a párkapcsolat szerkezetének hatása a válás esélyére. Az 1950-1954-es házasodási kohorszban 1,51-szer nagyobb esélye volt a hipogám 
kapcsolatoknak a válásra, mint egy hipergámoknak, és a homogám kapcsolatoknál is kevésbé tartósnak mutatkoztak. Időben csökkenő tendenciát követve, a 20002004-es házasodási kohorsz esetében már nem volt szignifikáns különbség a válás esélyében a hipogám és homogám kapcsolatok között. Ezzel egy időben a hipergám kapcsolatok válási esélye megnövekedett a homogám kapcsolatokhoz viszonyítva.

Schwartz és Han eredményei cáfolják az England által feltételezett késleltetett és egyoldalú átalakulást a nemek közötti viszonyokban, mivel a hipogám házasságok kezdeti magasabb válási esélye időben csökkent, majd megszűnt. A szerzők szerint a csökkenő tendencia oka az elmozdulás a merev, intézményesített nemi szerepektől az egalitárius, rugalmas párkapcsolati viszonyok felé. Ezzel egyidejüleg, a hipergám kapcsolatok válási esélyeinek megnövekedése jelentheti a párkapcsolatban megnyilvánuló férfidominancia iránti igény csökkenését.

Theunis és munkatársai Schwartz és Han eredményeire építve összetettebb formában vizsgálták a hipogám kapcsolatok terjedése és a párkapcsolat felbomlásának esélye közötti kapcsolatot belga adatok felhasználásával (Theunis et al. 2018). A mintába 458 499, 1986 és 2001 között megköttetett házasság került, melyben a feleség házasságkötéskori életkora 18-50 év között volt, és a házas felek nem rendelkeztek migrációs háttérrel. A házasságokban a férjek és feleségek relatív viszonyát végzettség szerint elemezték a szerzők.

Elemzésükben a hipogám kapcsolatok megoszlását nem országos, hanem régiós viszonylatban vizsgálták. Az 589 régiót a szerzők megkülönböztették aszerint, hogy mennyire elterjedtek a hipogám házasságok, három kategóriát alkotva (átlagos - 25-28\%, átlagon aluli - 14-25\%, átlagon felüli 28-46\%). A különböző régiókhoz való tartozás hatását a szerzők többszintű modellezési eljárásokkal vizsgálták.

Theunis és munkatársainak eredményei alapján a homogám kapcsolatokhoz képest a hipergám házasságok (1,16-szor) nagyobb eséllyel végződtek válással. Ezzel ellentétesen, a hipogám kapcsolatok válási esélye nem különbözött jelentős mértékben a homogám házasságokétól. A válási esélyekre jelentős hatással volt a hipogámia aránya a régiókban: a hipogám kapcsolatok válási rizikója alacsonyabb volt azon területeken, ahol e kapcsolatszerkezeti forma elterjedt volt, míg magasabb, ahol viszonylagosan ritkának számított. Schwarz és Han érvelését követve a szerzők szerint e kapcsolat oka, hogy az átlag feletti hipogám házaságokkal rendelkező régiókban a normák megengedőbbek, kevésbé vallásosak az egyének, és a nemi szerepek rugalmasabbak.

Míg Schwartz és Han (2014), valamint Theunis és munkatársai (2018) a normák változására vezetik vissza a hipogám kapcsolatok felbomlási esélyének időbeli csökkenését, addig Grow, Schnor és Van Bavel (2017) a párkapcsolati piacon jelentkező makrostrukturális változásokat helyezik középpontba.

A szerzők érvelése szerint az egyének kulturális és gazdasági okokból nemtől függetlenül az egyenlő vagy magasabb végzettségű partnereket preferálják párkereséskor. Mivel a nők végzettség tekintetében egyre nagyobb mértékben felülmúlják a férfiakat, 
így a homogám és hipogám kapcsolatok nagyobb eséllyel jönnek létre és maradnak fenn, kielégítve a jó társadalmi-gazdasági helyzetű partner iránti igényt. Ellentétes folyamat játszódik le a hipergám kapcsolatok esetében. A párkapcsolati piacon jelenlévő, alacsony végzettségű nők arányának csökkenésével kisebb eséllyel jön létre ilyen párkapcsolat, és a felek hajlamosabbak felbontani kapcsolatukat az elérhető nagyszámú, jobb társadalmi-gazdasági helyzetű potenciális alternatíva miatt.

A szerzők feltevésüket ágensalapú modellezéssel vizsgálták tizenkét európai országból származó adatokon. Az elemzett 1950 és 2004 között létrejött házasságok 12-14\%-a ért véget más partner választása miatt. Schwarz és Han eredményeit megerősítve, a végzettség tekintetében homogám kapcsolatok bomlottak fel a legkisebb eséllyel, valamint a hipogám kapcsolatok válási rizikója időben csökkenő tendenciát mutatott, 2000-2004-re pedig egyezett a hipergám házasságokéval. A szerzők szignifikáns kapcsolatot találtak a nők javuló végzettségi helyzete és a hipogám kapcsolatok válási esélyének csökkenése között - azaz, minél több magas végzettségú nő volt adott országban, annál kisebb eséllyel bomlottak fel a hipogám, és nagyobb eséllyel a hipergám kapcsolatok.

A vizsgált országok többsége az átlagoshoz közeli tendenciát követ, viszont egyes esetekben jelentős eltérések mutatkoztak. Dániában, Finnországban és Portugáliában idővel a hipogám házasságok válási esélye kisebb lett, mint a hipergám kapcsolatoké. Svédországban minden vizsgált kohorsz esetében a hipogám kapcsolatok maradtak fenn a legnagyobb eséllyel, ami időben erősödő tendenciát mutatott. Írország és az Egyesült Királyság esetében pedig nem volt csökkenés a hipogám kapcsolatok válási rizikójában. Az országok esetében tapasztalható heterogenitás oka az eltérő párkapcsolati piac összetételéből ered: az összefüggést nem mutató Írország és Egyesült Királyság esetében nem változott jelentősen a nemek aránya a magasan képzettek körében.

Ez az eredmény támogatja ugyan a vizsgálat kiinduló feltételezését, de a szerzők megjegyzik, hogy feltehetően a bemutatott lehetőségalapú folyamatok kiegészítik a Schwartz és Han esetében látott normaváltozás okozta hatásokat. A három kutatás eredményeiből megállapítható, hogy a párkapcsolati piacok átalakulását követi a homogám és hipogám párkapcsolatok megjelenése, ezzel egyidejúleg a párkapcsolatokra vonatkozó társadalmi normákban is változás következik be. A strukturális és normabéli átalakulás eredményeképp pedig a korábban instabilabbnak mutatkozó kapcsolatok időben elfogadottabbá, és ennélfogva stabilabbá váltak.

\section{Összegzés}

Jelen tanulmány témája a párkapcsolat szerkezetének hatása volt a kapcsolat stabilitására. A tanulmány során az adott elméleteket vizsgáló empirikus tanulmányok eredményei mellett bemutatásra kerültek a kérdés főbb megközelítései. 
Az ismertetett elméletek eltérő hatásokat feltételeztek a különböző relatív viszonyok függvényében. A specializációs modell a hipergám, egymásra utalt helyzetet tartotta stabilizáló hatásúnak, ezzel szemben a homofília elmélete az egyező társadalmi-gazdasági helyzetből következő hasonlóságot emelte ki, mint összetartó erőt. $\mathrm{Az}$ empirikus eredmények többnyire a specializációs modell feltevéseit igazolták, ugyanakkor rávilágítottak a relatív viszonyok részletesebb elemzésének szükségességére, valamint a szegénység kényszerűen összetartó hatására. A bemutatott kutatások eredményei egyöntetűen igazolták a kulturális sajátosságok esetén mutatkozó homogámia stabilizáló hatását.

A párkapcsolatokban a férfiak és nők egymáshoz viszonyított helyzetét egyes elméletek alkupozícióként értelmezték. Az alkudozási perspektíva szerint az egyenlőtlen szocioökonómiai viszonyok a kapcsolatban az egyik fél elnyomásához vezetnek a döntések során, ami instabilitást okoz. A relációs kohézió elmélete szerint viszont a heterogám és homogám kapcsolatok esetében is kialakulhat egy hosszan tartó párkapcsolat, jóllehet eltérő belső mechanizmusokon keresztül. Az empirikus eredmények szerint a házasságok esetében stabilnak a magas strukturális erőforrással rendelkező heterogám, míg az élettársi kapcsolatok közül az egyenlő hatalommal rendelkező homogám párkapcsolatok mutatkoztak.

A makroszintű hatások közül a párkapcsolati piac és a normák szerepe került bemutatásra. A párkapcsolati piac átalakulása hajlamosítja az egyéneket bizonyos összetételü kapcsolatok kialakítására, illetve a lehetséges jobb alternatívák számán keresztül befolyásolja a kapcsolatok stabilitását. A párkapcsolati piacok átalakulásával összefüggésbe hozható a normák változása is. Míg egyes elméletek szerint a nemek közötti viszonyok átalakulása lelassult és egyenetlen, az empirikus eredmények szerint a korábban kevésbé elterjedt kapcsolatszerkezeti típusok (kiemelten a hipogám kapcsolatok) számbeli növekedésével a társadalom is elfogadóbb lett e párok felé, így csökkentve a felbomlás esélyét.

Összességében a párkapcsolat stabilitását befolyásoló nagyszámú tényező közül a homogámia-heterogámia kérdése csak egy, azonban meghatározó körülmény. A jövőbeli elemzéseknek nem csak a pár tagjainak relatív helyzetét, hanem az őket körülvevő társadalmat és annak normáit is figyelembe kell venniük.

\footnotetext{
Abstract: In this paper, I examine the connection between the structure of a relationship and the probability of dissolution by presenting the main theoretical frameworks and selected empirical results. One of the most often employed theory regarding this connection is Becker's model, which emphasizes specialization and interdependence in a relationship. Opposed to the specialization model, other theories highlight the possible positive effects of similarity, such as mutual worldview, better communication and similar lifestyles. Empirical results mostly confirm the specialization model. The bargaining perspective focuses on the asymmetric bargaining positions inside a relationship, which stem from unequal socioeconomic positions, and effect day-to-day decisions and increase the relationship's instability. According to the theory of relational cohesion, which is related to the bargaining perspective, increased marital stability can originate from unequal and equal relative positions too. The
} 
presented results are in line with the theory of relational cohesion. When examining the link between relationship stability and structure, the consideration of relationship markets and norms are essential. Macrostructural conditions may increase the probability of certain relationship structures, and the number of available alternative partners affect dissolution probabilities. Norms influence how society judges certain relationships (thereby affecting the probability of dissolution), however the stalled revolution viewpoint theorizes that changes in norms are lagging behind structural changes. According to the results, as norms and relationship markets change, non-traditional relationships spread, and their instability decreases.

Keywords: homogamy, structure of the relationship, specialization, dissolution, divorce

\section{Irodalom}

Becker, G. S. (1973): A theory of marriage. Part I. Journal of Political Economy, 81(4): 813-846. https://doi.org/10.1086/260084.

Becker, G. S. (1974): A theory of marriage. Part II. Journal of Political Economy, 82(2): S11-S26. https://doi.org/10.1086/260287

Becker, G. S. (1981): A Treatise on the Family. Cambridge: Harvard University Press.

Bittman, M. - England, P. - Sayer, L. - Folbre, N. - Matheson, G. (2003): When does gender trump money? Bargaining and time in household work. American Journal of Sociology, 109(1): 186-214. https://doi.org/10.1086/378341.

Bittman, M. - England, P. - Sayer, L. - Folbre, N. - Matheson, G. (2001): When gender trumps money: Bargaining and time in household work. Interneten: http://citeseerx.ist.psu.edu/viewdoc/download?doi=10.1.1.24.1215\&rep=rep1\& type=pdf (letöltve: 2019.10. 11.).

Blau, P. M. (1977): A macrosociological theory of social structure. The American Journal of Sociology, 83(1): 26-54. https://doi.org/10.1086/226505.

Blossfeld, H. P. - Timm, A. (2003): Educational systems as marriage markets in modem societies: A conceptual framework. In Blossfeld, H. P. - Timm, A. (eds.): Who Marries Whom? Educational Systems as Marriage Markets in Modern Societies. Dordrecht: Kluwer Academic Publishers, 1-18. https://doi.org/10.1007/978-94007-1065-8.

Brennan, R. T. - Barnett, R. C. - Gareis, K. C. (2001): When she earns more than he does: A longitudinal study of dual-earner couples. Journal of Family and Marriage, 63(1): 168-182. https://doi.org/10.1111/j.1741-3737.2001.00168.x.

Brines, J. - Joyner, K. (1999): The ties that bind: Principles of cohesion in cohabitation and marriage. American Sociological Review, 64(3): 333-355. https:// doi.org/10.2307/2657490.

Bukodi E. - Róbert P. (2000): Vagyoni helyzet - Kulturális fogyasztás. In. Kolosi T. - Tóth I. Gy. - Vukovich Gy. (szerk.): Társadalmi Riport 2000. Budapest: TÁRKI, 346-376.

England, P. (2010): The gender revolution: Uneven and stalled. Gender and Society, 24(2): 149-166. https://doi.org/10.1177/0891243210361475. 
Eurostat (2019): Marriage and divorce statistics. Interneten: https://ec.europa.eu/ eurostat/statistics-explained/index.php/Marriage_and_divorce_statistics (letöltve: 2019. 10. 11.).

Frimmel, W. - Halla, M. - Winter-Ebmer, R. (2012): Assortative mating and divorce: Evidence from Austrian Register Data. Journal of the Royal Statistical Society, 176(4): 907-929. https://doi.org/10.1111/j.1467-985X.2012.01070.x.

Gödri I. (2001): A házassági kapcsolatok minősége és stabilitása. Elméleti támpontok és mérési lehetőségek. Központi Statisztikai Hivatal Népességtudományi Kutatóintézetének kutatási jelentései 66. Budapest: KSH-NKI.

Grow, A. - Schnor, C. - Van Bavel, J. (2017): The reversal of the gender gap in education and relative divorce risks: A matter of alternatives in partner choice? A Journal of Demography, 7(sup1): 15-34. https://doi.org/10.1080/00324728.201 7.1371477.

Jalovaara, M. (2003): The joint effects of marriage partners' socioeconomic positions on the risk of divorce. Demography, 40(1): 67-81. https://doi. org/10.2307/3180812.

Kalmijn, M. (1998): Intermarriage and homogamy: Causes, patterns, trends. Annual Review of Sociology, 24(1): 395-421. https://doi.org/10.1146/annurev. soc.24.1.395.

Kraft, K. - Neimann, S. (2009): Impact of educational and religious homogamy on marital stability. IZA Discussion Paper No. 4491. Interneten: https://dnb.info/997679484/34 (Letöltve: 2019. 10. 11.).

Lawler, E. J. - Yoon, J. (1993): Power and the emergence of commitment behavior in negotiated exchange. American Sociological Review, 58(4): 465-481. https://doi. org/10.2307/2096071.

Lawler, E. J. - Yoon, J. (1996): Commitment in exchange relations: Test of a theory of relational cohesion. American Sociological Review, 61(1): 89-108. https://doi. org/10.2307/2096408.

Makay Zs. - Szabó L. (2018): Válás. In. Monostori J. - Őri P. - Spéder Zs. (szerk.): Demográfiai Portré 2018. Budapest: KSH Népességtudományi Kutatóintézet, 29-47.

Ono, H. - Lee, K. S. (2008): Specialization and happiness in marriage: A U.S.-Japan comparison. Social Science Research, 37(4): 1216-1234. https://doi.org/10.1016/j. ssresearch.2008.02.005.

Oppenheimer, V. K. (1997): Women's employment and the gain to marriage: The specialization and trading model. Annual Review of Sociology, 23(1): 431-453. https://doi.org/10.1146/annurev.soc.23.1.431.

Pilinszki A. (2015): A párkapcsolati instabilitást meghatározó tényezők. Socio.hu: Társadalomtudományi Szemle, 5(1): 232-245.

Rapp, I. - Klein, T. - Fronk, S. - Stauder, J. (2015): Partner market opportunities and relationship stability. Comparative Population Studies, 40(3): 229-250. https:// doi.org/10.12765/CPoS-2015-08en. 
Sági M. (2000): Kulturális szegmentáció: „Mindenevők”, „Válogatósak”, „Egysíkúak” és „Nélkülözők”? Az „omnivore-univore” modell alkalmazhatósága Magyarországon. In Kolosi T. - Tóth I. Gy. (szerk.): Társadalmi Riport 2010. Budapest: TÁRKI, 288-311.

Schwartz, C. R. - Han, H. (2014): The reversal of the gender gap in education and trends in marital dissolution. American Sociological Review, 79(4): 605-629. https://doi.org/10.1177/0003122414539682.

Simpson, I. H. - England, P. (1981): Conjugal work roles and marital solidarity. Journal of Marriage and Family Issues, 2(2): 180-204. https://doi. org/10.1177/0192513X8100200205.

South, S. J. - Trent, K. - Shen, Y. (2001): Changing partners: Toward a macrostructural-opportunity theory of marital dissolution. Journal of Marriage and Family, 63(3): 743-754. https://doi.org/10.1111/j.1741-3737.2001.00743.x.

Theunis, L. - Schnor, C. - Willaert, D. - Van Bavel, J. (2018): His and her education and marital dissolution: Adding a contextual dimension. European Journal of Population, 34(4): 663-687. https://doi.org/10.1007/s10680-017-9448-y.

Tichenor, V. J. (1999): Status and income as gendered resources: The case of marital power. Journal of Marriage and the Family, 61(3): 638-650. https://doi. org/10.2307/353566.

Van Hek, M. - Kraaykamp, G. - Wolbers, M. H. J. (2016): Comparing the gender gap in educational attainment: The impact of emancipatory contexts in 33 cohorts across 33 countries. Educational Research and Evaluation, 22(5-6): 260-282. https://doi.org/10.1080/13803611.2016.1256222. 